\title{
AOR
}

Selected Papers of \#AoIR2021:

The 22nd Annual Conference of the

Association of Internet Researchers

Virtual Event / 13-16 Oct 2021

\section{RECKONING AND REPAIR: THE URGENT CONVERSATION ABOUT RACE IN THE BLACK, CHRISTIAN PODCAST CIRCUIT}

\author{
Corrina Laughlin \\ Loyola Marymount University
}

Through a critical discourse analysis of three podcasts and interviews with prominent Black Christian podcasters, this paper focuses on the Black Christian response to the 2020 uprisings against police brutality in the United States. I argue that the Black, Christian podcast circuit is a counterpublic (Squires, 2002) that seeks to change Christian culture in America. The affordances of the medium of podcasting offer podcasters a space to create both a counterpublic and an enclaved public. And this dual nature of the medium that makes it a potent force for changing the Christian conversation about race. The podcasters I profile offer a portrait of a divided Christian church in need of repair and they make the case that repair is only possible through decolonizing the Christian faith, repenting and offering reparations for the racial trauma caused by white Christians, sparking Christians' activist inclinations in favor of racial justice causes, and interrogating and correcting sexism within both the Black church and white evangelical culture.

Catherine Squires (2002) has written about Black counterpublics and she schematizes Black counterpublic spaces in three ways: enclaved publics, counterpublics, and satellite publics. Enclaved publics remain shielded or hidden, perhaps, for example, to protect the safety of their members under conditions of repression. Satellite publics may engage with the broader public sphere, while remaining separate from it. By contrast, Black counterpublic spaces actively engage the broader public sphere as a way to force change within it. Sarah Florini's (2015) study of black podcasters argues that the power of podcasting lies in the fact that it can be a site of enclaved discourse. She writes of the habitus of podcast listening that "many of these listeners consume podcasts via headphones in predominantly white spaces where they work or live, and may to some degree be 'cocooning' themselves in the sounds of Black sociality as they navigate a hegemony that constitutes white culture as normative" (Florini, 2015). And, Brock (2020) argues that Black users have carved out Black spaces in a digital culture where the assumed user is a white male and they have done so by performing Blackness. In this process networked Black users have defined Black technocultures, which, he writes, connect Black cultural practices to information technology use. Black listeners can

Suggested Citation (APA): Laughlin, C. (2021, October). Reckoning and repair: The urgent conversation about race in the Black, Christian podcast circuit. Paper presented at AolR 2021: The 22nd Annual Conference of the Association of Internet Researchers. Virtual Event: AolR. Retrieved from http:// spir.aoir.org. 
retreat into Black spaces through the habitus of podcast listening as Florini and Brock argue, and this was backed up by my interviewees. One podcaster explained, for example, that when he addresses his audience, "I want to code myself as Black because here's what happens if I speak to black Christians directly, there are other Christians that can feel as though, okay, I identify what's being said, but if I speak to white Christians directly, then Black Christians will feel excluded and alienated and further marginalized" (Burns, 2020).

But, the podcasters that I spoke with for this paper also share the goal of changing Christian culture and that means talking to and trying to influence white Christians. Another podcaster told me, "We speak directly to white evangelicals because there's a lot of them they're oftentimes part of what impedes Black freedom in the church or beyond, so in my view, they need to be in the conversation." The public sphere of evangelicalism, which is comprised of publishing houses, magazines, television shows and channels and podcasts, has been controlled by the mostly white evangelical gatekeepers of the Christian media world. And many of these gatekeepers have proven that they are willing to block voices that do not conform to what is considered the norms of white evangelicalism (see Laughlin, 2019). But with the rise of podcasts, Christians can side step these cultural authorities they can create spaces that are defined in and through the Black experience, and they can also use these conversations as a space to push their own discourses into the broader public's consciousness. To create a space for their own community and to influence the larger public, Black Christian podcasters create both an enclaved space where Black listeners can feel at home and cocoon themselves in Black cultural idioms, and a counterpublic space that engages with - and hopes to change - the larger Christian public.

One podcaster explained his understanding of the power of podcasting:

The greatest concern of white supremacists, white Christian nationalism, is that Black people and Black Christians will control their own narrative. And that's when we become dangerous. And that's when we become free is now we can tell people, no, what they said is actually wrong. No, that's wrong. And then they can't shut us down. And that's why it's such a threat yet at the same time, such a powerful medium as well.

This paper looks at one communicative mode, the podcast, to think through the role that this media form has played in in helping to force a reckoning about race in American Christian culture. While "racial reconciliation" has been in the evangelical lexicon for decades (see Du Mez, 2020, Chapter 9), it is a discourse that has typically been promoted by white evangelicals and has been constructed on their terms. But in 2020, the white gatekeepers that once led the conversation were sidelined by passionate Black media makers who created new activist spaces with the intent of reshaping the narrative to match the urgency of the moment.

\section{Selected References}

Brock, A. (2020). Distributed Blackness: African American cybercultures. New York: NYU Press.

Du Mez, K. K. (2020). Jesus and John Wayne: How white evangelicals corrupted a faith 
and fractured a nation. New York: Norton.

Florini, S. (2015). The Podcast "Chitlin" Circuit": Black Podcasters, Alternative Media, and Audio Enclaves." Journal of Radio \& Audio Media, 22(2), 209-219.

Laughlin, C. (2020). \#AmplifyWomen: the emergence of an evangelical feminist public on social media. Feminist Media Studies.

Squires, C. R. (2002). Rethinking the Black Public Sphere: An Alternative Vocabulary for Multiple Public Spheres. Communication Theory (10503293), 12(4), 446. 